\title{
Post-vaccinal reaction for some vaccines used against Newcastle disease in Sulaimaniyah province
}

\author{
E.A. Abdul Ahad \\ Coll. of Vet. Med.I Unive. of Sulaimaniyah
}

\begin{abstract}
This study was conducted to investigate the safety of the most commonly used Newcastle disease vaccines in Al-Sulaimaniyah province (LaSota and Clone30). A total of 225 one-day old broiler chicks of Ross 308 breed were investigated for their maternal-derived antibody (MDA) titers by ELISA test. Subsequently, these chicks were divided randomly into 3 equal groups; ( 2 treatment groups, T1 group which was vaccinated by LaSota vaccine and T2 group which was vaccinated by Clone30 vaccine). and control non-vaccinated group. ELISA test was used to investigate the antibody titers against NDV in all groups on day 10 post second vaccination at 34 days of chicks age and tissue biopsies were obtained for histopathological examination from the trachea, spleen, Bursa of Fabricious and thymus to explore the tissue changes that may induced by the vaccine.Significant variation was observed in the means of antibody titers against NDV between the control and treatment groups, whereas, no significant variation was observed between the treatment groups themselves. The histopatological examination results showed that a reactive lymphocytic response was observed in both treatment groups compared to the control group. In addition, focal epithelial sloughing and mucopurulent exudates was observed in the trachea of T1 group chicks only. The result of this study showed that the NDV vaccine of clone30 is approximately of the same efficiency and more secure than LaSota vaccine.
\end{abstract}

\section{Introduction}

Newcastle disease (ND) is a highly contagious viral disease of poultry and other birds species caused by a specific virus belonging to Avian Paramyxovirus type 1 (APMV-1) serotype of genus Avulavirus, sub-family Paramyxovirinae of family Paramyxoviridae $(1,2)$. The virus has a wide host rang, and more than (250) species of birds have been reported as susceptible to infection (8). Strains of (ND) viruses are distinguished into five serotypes (3) on the basis of clinical signs in infected chickens and other birds. These are viscerotropic velogenic Newcastle disease virus (vvNDV), neurotropic velogenic virus (nvNDV), mesogenic virus, lentogenic virus and a symptomatic enteric virus. The virulent $\mathrm{ND}$ viruses can replicate in a wide range of tissues and organs resulting in sever systemic infection, whereas the low virulent ND viruses can only replicate in areas with trypsin-like enzymes such as in respiratory and intestinal tracts causing transient epithelial damage which may provide a route for secondary bacterial infection, a common post-vaccination complications (4,5,6).Vaccination of chickens against Newcastle disease is routinely practiced throughout the word (7). Ideally, vaccination against NDV would result in immunity against infection and replication of the virus, but Realistically, ND vaccination usually protects the birds from the more serious consequences of disease, but virus replication and shedding may still occur, albeit a reduced level $(12,16)$. It should be emphasized that in no circumstances can vaccination be regarded as an alternative to good management practice, biosecurity, or good hygiene in rearing domestic poultry(13).Vaccination against ND can be performed with either live or inactivated vaccines. Live vaccines induce higher protection and have been used in poultry industry for more than 50 years. They are based on the use of Lentogenic strains, among which Hitchner B1 and LaSota are the most popular (8). The efficiency of a live vaccine depends on its potency to multiply enough within the 
chicken to induce a satisfactory immune response (9). Lentogenic strains can be used only in birds with low level of or no maternal antibodies, but not in areas where ND is caused by virulent strains and is endemic. Chicks with higher level of maternal antibodies vaccinated by the respiratory rout while in the hatchery, or in the first four days of life do not respond by specific antibodies production but are still protected because of the local immunity developed, and secondary vaccination is required (11).Researchers observed that vaccination with the LaSota strain of Newcastle disease virus intranasally can induced tracheal lesions, diciliation of the

tracheal surface, hypertrophy of goblet cells, their rupture and formation of excess mucus. These lesions are detrimental to epithelial integrity and function as a barrier against invading microorganisms, that might explain at the ultrastructural level the secondary complications of vaccination with LaSota strain against Newcastle disease virus $(36,38)$. The objective of the present study was to investigate the post-vaccinal pathological changes of different vaccine strains and routes against Newcastle disease virus (NDV) to be sure of the most safety one to be used in some poultry farms in Sulaimaniyah provincel Iraqi Kurdistan region.

\section{Materials and Methods}

\section{Vaccines:}

Commercial vials of live attenuated vaccines (Lyophilized) were bought from Regional Agency of Ceva company (France) .and Intervet company (Holland) as follows:

1- Ceva New L® (NDV LaSota strain/ Lentogenic. Lyophilized vial of 1000 dose).

2- Clone VAC-30 ® (NDV Clone30 strain/Lentogenic. Lyophilized vial of 1000 dose).

\section{Experimental Design:}

A total of 225 one-day old broiler chicks of Ross 308 breed were received from Lao-Lao hatchery\ Sulaimaniyha I Kurdistan region VIraq. The chicks were reared for 42 days (January, $6^{\text {th }}$ - February, $17^{\text {th }}, 2010$ ) on floor under similar healthy environmental circumstances. The feed was formulated as balanced ration according to National Research Center (NRC) recommendations (14). The chicks were randomly divided into 3 groups $(\mathrm{C}=$ control group, $\mathrm{T} 1=$ first treatment group, $\mathrm{T} 2=$ second treatment group) of 75 chicks. The chicks in each group were further divided into $3 \mathrm{sub}$ groups of 25 chicks. Chicks of control group (C group) were kept unvaccinated, whereas chicks of treatment group T1 and chicks of treatment group T2 were vaccinated on 13, 24 day old as follows:
1- Chicks of treatment group T1were vaccinated with $0.1 \mathrm{ml} /$ chick (one vaccine dose) of NDV LaSota strain via drinking water, Eye-drop and Naso-drop.

2- Chicks of treatment group T2 were vaccinated with $0.1 \mathrm{ml} /$ chick (one vaccine dose) of NDV Clone30 strain via eye-drop and naso-drop.

\section{Serological Examinations:}

Blood samples were collected for measurement of Maternal-Derived Antibodies (MDA) by indirect Enzyme Linked Immunosorbent Assay (ELISA) (17) on $3^{\text {rd }}, 7^{\text {th }}$ and $12^{\text {th }}$ days of chick's age (prior to vaccination). Other blood samples were collected for measurement of VaccineDerived Antibodies on day 10 post first vaccination and on days 7 and 10 post second vaccination.

\section{Histopathological Examinations:}

Tissue samples (Trachea, Spleen, Thymus and Bursa of Fabricius ) were obtained from chicks of all groups for histopathological examination on days 3,5 and 10 post first vaccination. In addition, tissue samples were obtained on days 4 and 10 post second vaccination. The obtained samples were processed for routine histo-technique and staining according to Luna (15). 


\section{Statistical Analysis}

The data were collected and processed using Statistical Analysis System (SAS.1988) (37).

\section{Results}

\section{Maternal and vaccinal - derived antibodies titers}

The measurement of maternal-derived antibodies (as indicated by ELISA test) showed a marked decline of antibodies on day 12 of chicks age (Table, 1). On the other hand, the measurement of vaccinalderived antibodies titers showed a significant variation $(\mathrm{P}<0.05)$ between control and treatment groups at 10 days post second vaccination (34 days of age). In addition, the antibodies titer was nonsignificantly $(\mathrm{P}<0.05)$ higher in treatment group $\mathrm{T} 1$ than in treatment group T2 (Table. 2).

Table 1. Means of maternal-derived antibody titer (MDA) against ND virus in experimental chicks as measured by ELISA test.

\begin{tabular}{||l|l||}
\hline Age (days) & Means \pm SE of maternal-derived antibody titer \\
\hline \hline 3 & $6823 \pm 924.72$ \\
\hline 12 & $5789 \pm 744.13$ \\
\hline
\end{tabular}

Table 2. Means of antibody titer against ND virus on 10 days post second vaccination (at day 34 of chicks age) as measured by ELISA test in chicks of all groups.

\begin{tabular}{|l|l||}
\hline Groups & Means \pm SE of antibody titer \\
\hline \hline Control & $0.0 \pm 717.22^{\mathrm{a}}$ \\
\hline Treatment T1 & $8097 \pm 717.22^{\mathrm{b}}$ \\
\hline Treatment T2 & $7250 \pm 717.22^{\mathrm{b}}$ \\
\hline
\end{tabular}

Within a row, the titers of antibodies that do not have common small letter superscripts vary from each other $(\mathrm{P}<0.05)$.

\section{Clinical and histopathological findings}

No signs of illness were observed on the control and treated chicks during the days that followed the first vaccination, whereas moderate respiratory signs represented by sneezing and coughing were observed only on chicks of treatment group T1 during the first few days after the second vaccination. The result of histopathological examination which was performed on days 3-5 and 10 post first vaccination and on days 4 and 10 post second vaccination showed no significant lesions in chicks of the control group in comparison to some pathological changes in chicks of treatment groups T1 and T2 represented by focal epithelial sloughing and mucopurulent exudates in the trachea associated with blood vessels congestion and infiltration of mononuclear inflammatory cells (Figure.1 and 2 ) in chicks of treatment groups T1 and marked lymphocytic hyperplasia in the spleen ( Figure 3 and 4), bursa of fabricius (Figure 5 and 6 ) and thymus (Figure 7 and 8 ) in chicks of both treatment groups. 


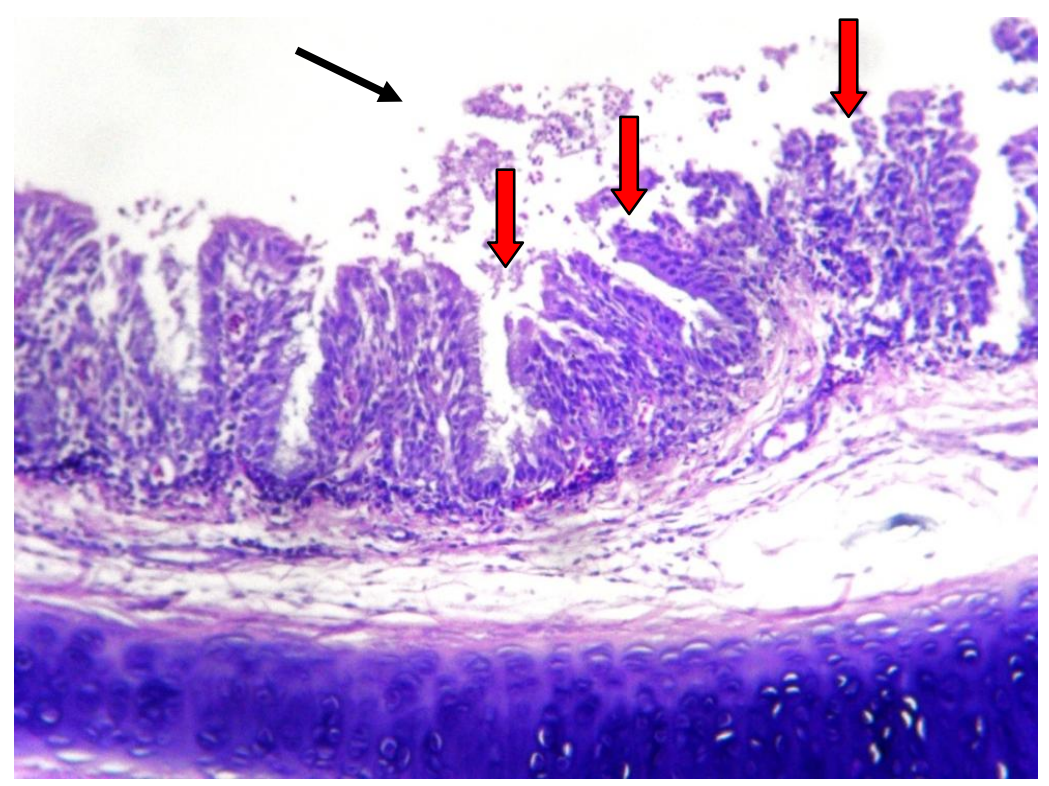

Figure 1: Microscopic view of a tissue section obtained from the trachea of a chick in treatment group T1. It shows mucopurulent exudate (black thin arrow) in the tracheal lumen and focal epithelial sloughing (red thick arrows). Blood vessels congestion and infiltration with few numbers of mononuclear inflammatory cells are also apparent in the mucosal and submucosal layers, X100.

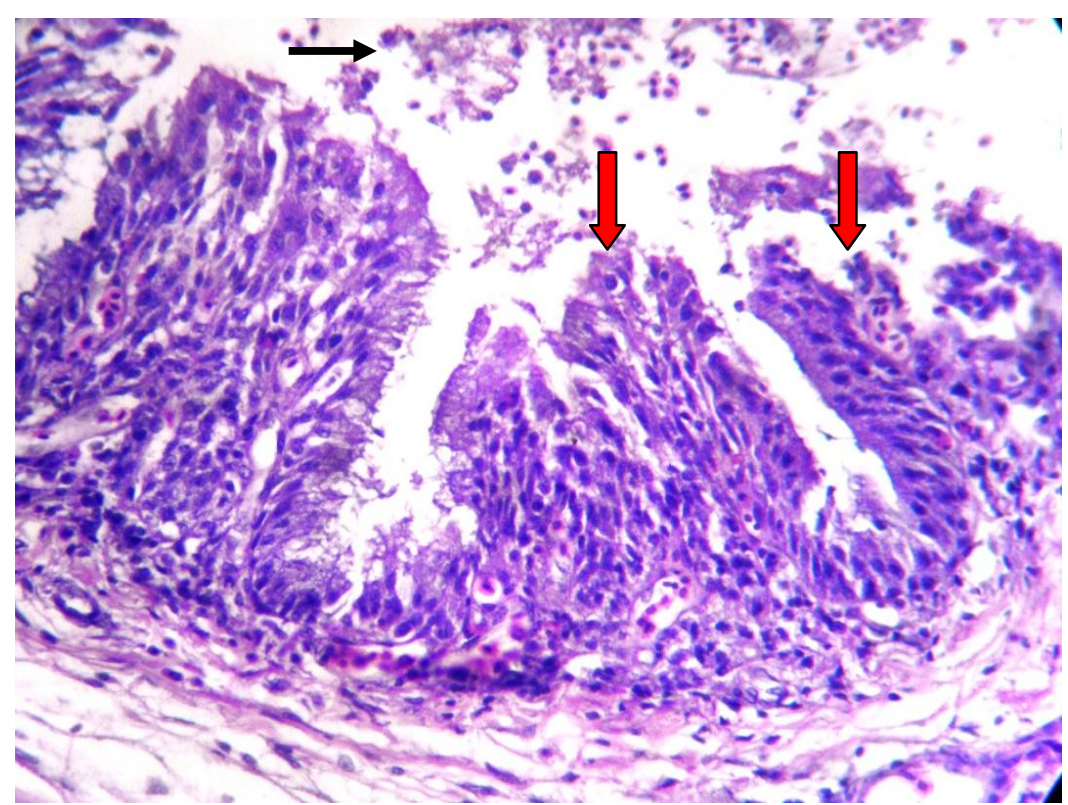

Figure 2: Higher microscopic view of the tissue section illustrated in figure 1. Mucopurulent exudate (black thin arrow) is apparent in the tracheal lumen associated with focal epithelial sloughing (red thick arrows). Blood vessels congestion and infiltration with few numbers of mononuclear inflammatory cells are also evident in the mucosal and submucosal layers, X200. 


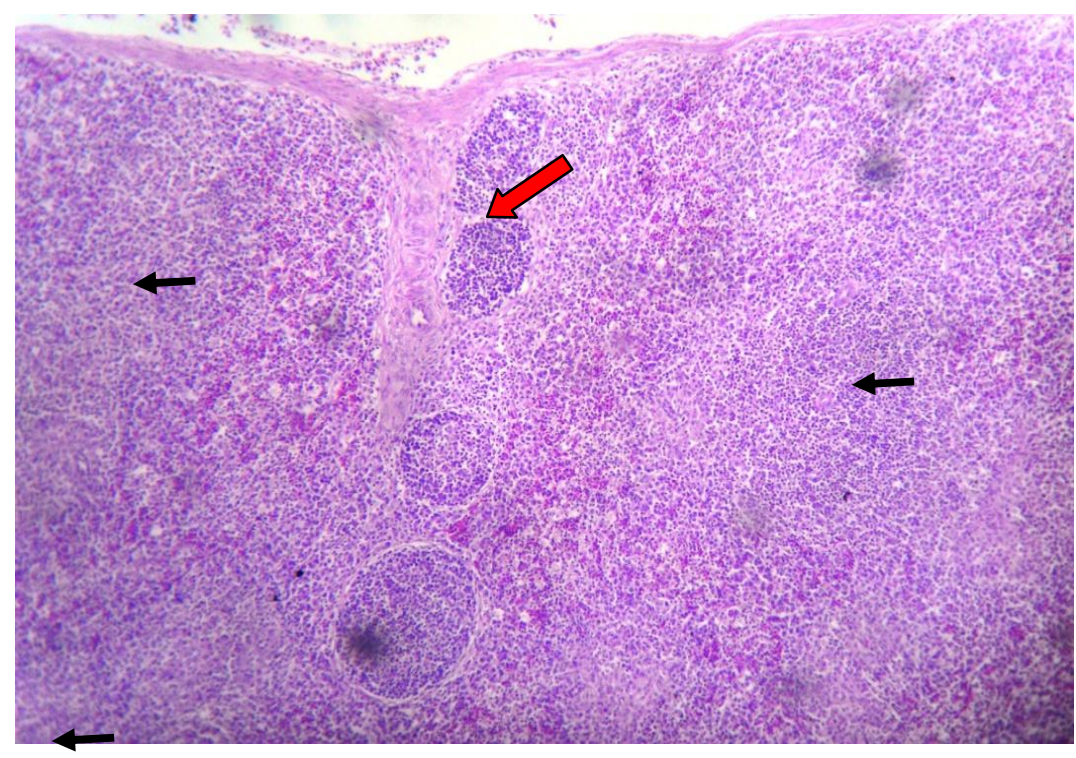

Figure 3: Microscopic view of a tissue section obtained from the spleen of a chick in the treatment group T2. It shows reactive follicular hyperplasia (red thick arrows) in the white pulp associated with blood vessels congestion and slight lymphocytic proliferation (black thin arrows) in the red pulp, X100.

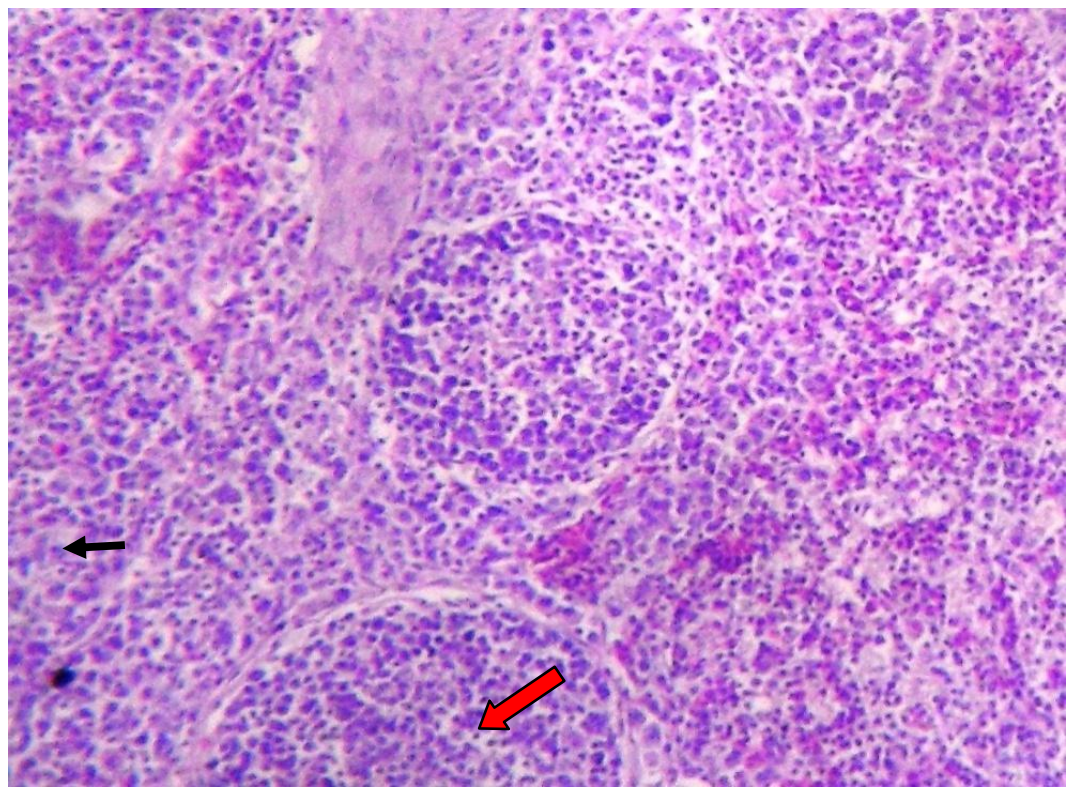

Figure 4: Higher microscopic view of the tissue section illustrated in figure 3. Reactive follicular hyperplasia (red thick arrows) is apparent in the white pulp associated with blood vessels congestion and slight lymphocytic proliferation (black thin arrow) in the red pulp, X200. 


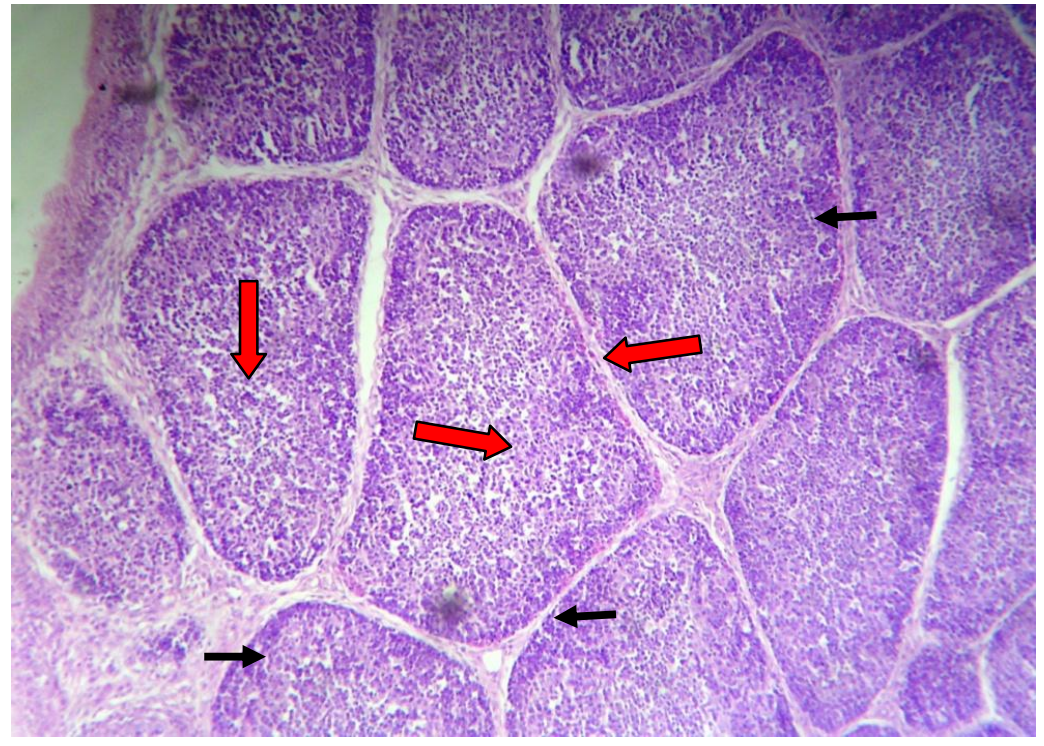

Figure 5: Microscopic view of a tissue section obtained from the Bursa of Fabricius of a chick in the treatment group T1. It shows cortical lymphocytic hyperplasia (red thick arrows) and infiltration with heterophils at the periphery of the cortex in some of the bursal follicles (black thin arrows), X100.

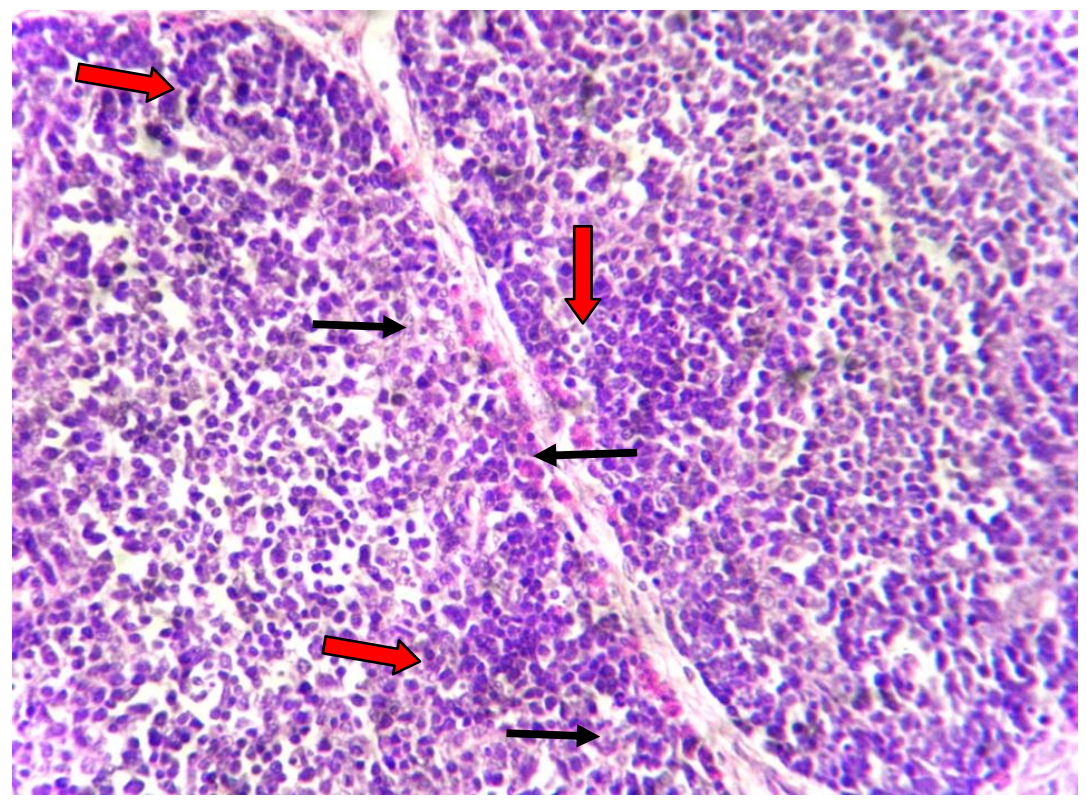

Figure 6: Higher microscopic view of the tissue section illustrated in figure 5. Lymphocytic hyperplasia is apparent in the follicular cortex (red thick arrows) accompanied by infiltration with heterophils at the periphery of the cortex in some of the bursal follicles (black thin arrows), X200. 


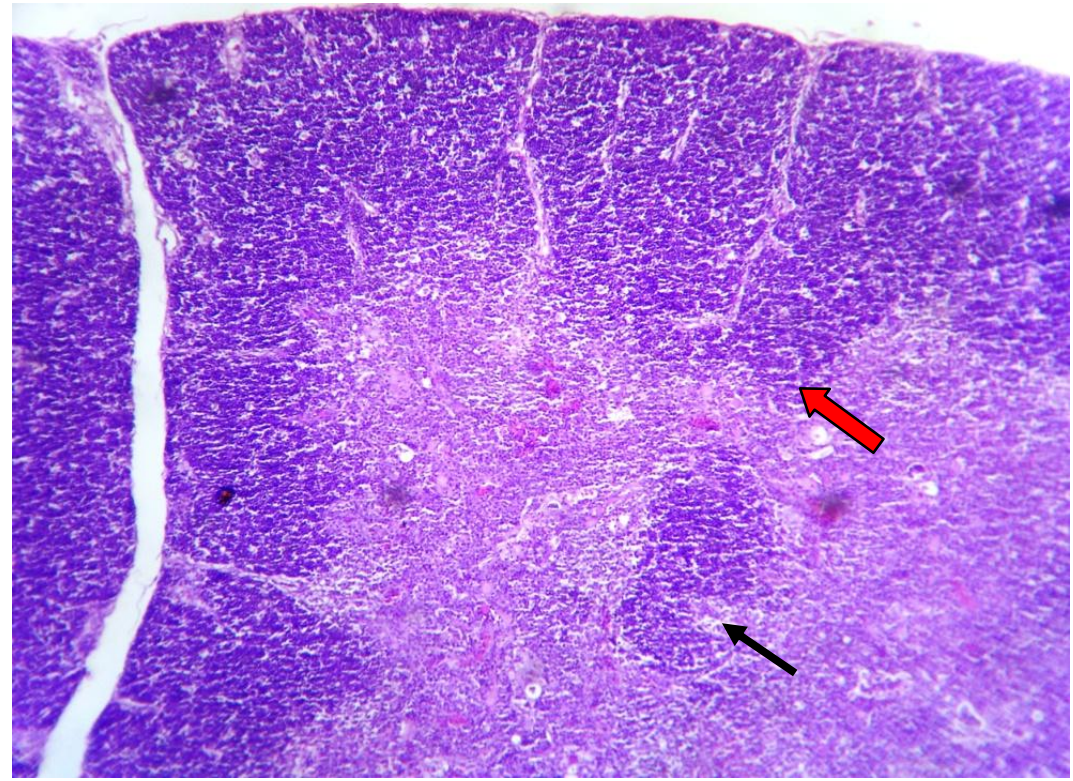

Figure 7: Microscopic view of a tissue section obtained from the thymus of a chick in treatment group T2. It shows cortical (red thick arrow) and medullary (black thin arrow) lymphocytic hyperplasia, X100.

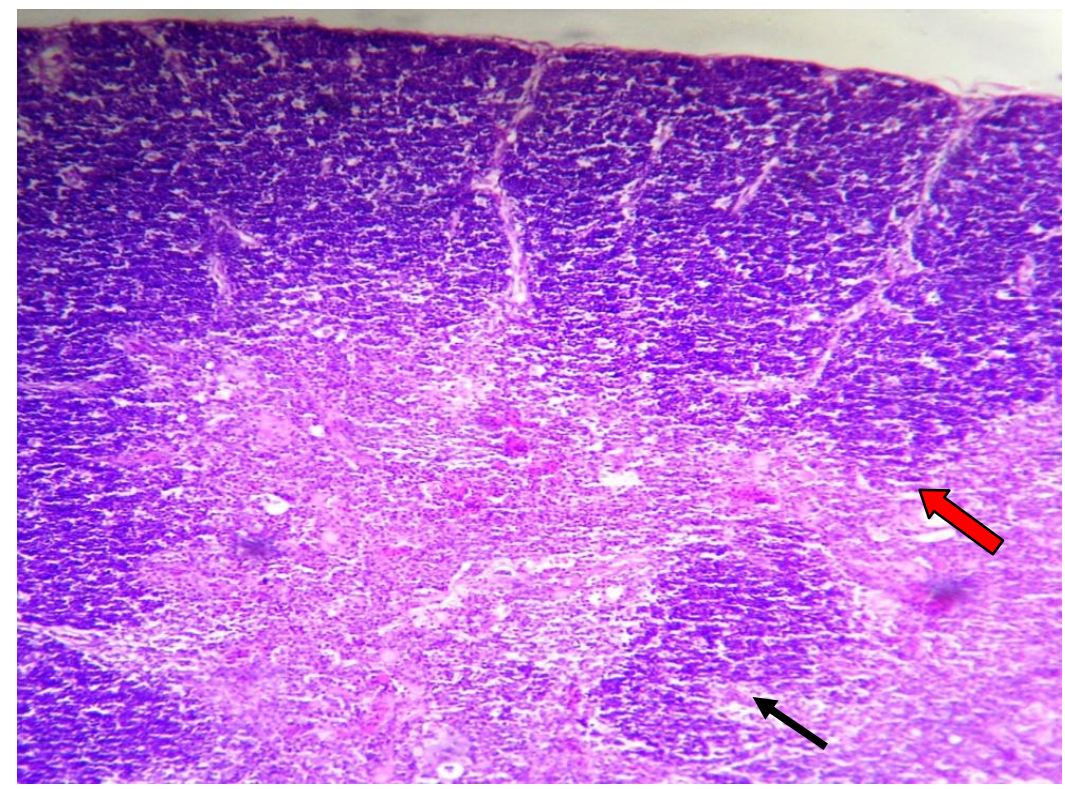

Figure 8: Higher microscopic view of the tissue section illustrated in figure 7. Lymphocytic hyperplasia is apparent in the cortex (red thick arrow) and medulla (black thin arrow) of the thymic lobule, X200.

\section{Discussion}

The decline in maternal-derived antibodies that was observed on day 12 of chick age indicates that the titer of this type of immunity against NDV persists through the first two weeks of chicks age. This finding is compatible with those reported by $(18,19,20,21,22,23,24,25,26)$.On day 10 post second vaccination (day 34 of chicks age), a significant variation was observed in antibody titers against NDV 
between the control and treatment groups. This result which is in agreement with finding of $(19,30)$ indicates that a protective humeral immune response was induced in both treatment groups by the NDV strain vaccine in comparison with the control group. Regarding the treatment groups themselves, a non- significant rise in antibodies titer was observed in treatment group T1 compared to treatment group T2. This finding is in agreement with $(27,28)$ who mentioned that NDV vaccine of LaSota strain induce superior immunity than the other lentogenic strain, however, in this study this superiority was observed but it was non-significant, this non-significance variation might be due the dose and the route used in vaccination which play an important role in the level of the induced immunity $(28,29,31,32)$. The moderate respiratory sings (sneezing and coughing) observed on chicks of treatment group T1 during the first few days after the second vaccination dose are probably attributed to the pathogenic nature of the vaccine (LaSota) used for immunization of this group as indicated by the epithelial sloughing, and the mucopurulant exudates observed in the trachea of chicks of this group. This result is in agreement with finding of $(3,33,34)$ who mentioned that NDV vaccine of LaSota strain is more pathogenic than other lentogenic vaccines. The marked lymphocytic hyperplasia that observed in the spleen, bursa of fabricius and thymus in both treatment groups is in agreement with findings of $(10,33,34,35$, 36,38 ) and it can be ascribed to the immune response that induced by the vaccines. The result of this study showed that the NDV vaccine of Clone 30 is approximately of the same efficiency as the LaSota vaccine as indicated by the nonsignificant variation observed in antibodies titer and the marked lymphocytic response observed on spleen, bursa of fabricius and thymus in both groups. In addition, the NDV vaccine of clone30 appeared to be more secure than NDV vaccine of LaSota strain as indicated by the moderate clinical respiratory sings that were observed in treatment group T1 chicks which showed focal epithelial sloughing and mucopurulant exudates in their tracheas.

\section{References:}

1. De Leeuw O. , Peeters B. (1999); Complete nucleotide sequence of Newcastle disease virus. Evidence for the existence of a new genus within the subfamily Paramyxovirinae. J. Gen. Viral, 80: 131-136.

2. Mayo M.A. (2002); A summary of taxonomic changes recently approved by ICTV. Arch .Virol., 147:1655-1656.

3. Beard C.W, Hanson R.P. (1984); Newcastle disease. In Diseases of Poultry. (Hofstad MS, Barnes HJ, Calnek BW, Reid WM \& Yoder HWeds), 8th edn, Iowa State University Press, Ames, Iowa, pp: 452-470.

4. Abdul-Aziz T.A, Arp L.H. (1983); Progression of tracheal lesions in turkeys exposed by aerosol to LaSota strain of Newcastle disease virus. Avian Dis. 27:1131-1136.

5. El Tayeb A.B, Hanson R.P. (2002); Interactions between Escherichiacoli and Newcastle disease virus in chickens. Avian Dis. 46:660-667.

6. Nakamura $K$, Narita $M$, Imai $K$, Matsumura T, Maeda M, Tanimura T. (1992); The effect of mixed live vaccines of Newcastle disease and infectious bronchitis on the chicken Respiratory tract. J .Comp .Pathol. 106:341-350.

7. Rahman M.M., Bar. A.S.M., Giasuddin M., Islam M.R., Alam J,Sil G.C., Rahman M.M. (2002); Evaluation of maternal and humeral immunity against Newcastle disease virus in 
chicken. Interna. J .Poult. Sci.;1 (5):161-163.

8. Alexander D.J (2000); Newcastle disease and other avian paramyxoviruses. Rev. Sci. Tech. OIE, 19: 443-462.

9. Meulemans G. (1988); Newcastle disease: control by vaccination. In: Developments in Veterinary Virology: Newcastle Disease, ed. Alexander DJ, Kluwer AcademicPublishers, Deventer, The Netherlands, pp: 318-332.

10. Borland L.J, Allan W.H, (1980); Laboratory tests for comparing live lentogenic Newcastle disease vaccines. Avian Pathol. 9: 45-59.

11. Mazija H, Bidin Z, Stajer A, Mikec M. (1981); Emergency vaccination against Newcastle disease. Praxis vet.; 29: 45-52.

12. Guittet M., Le Coq H., Morin M., Jestin V., and Bennejean. G. (1993); Distribution of Newcastle disease virus after challenge in tissues of vaccinated broilers. In Proceedings of the Xth World Veterinary Poultry Association Congress, Sydney, 179.

13. Thornton, D. H.(1988); Quality control of vaccines. In Alexander D. J. (ed.). Newcastle Disease. Kluwer Academic Publishers: Boston, MA. 347-365.

14. National Research Council (NRC),(1994); Nutrients Requirements of Poultry. $9^{\text {th }} \cdot$ Rev. Edn. National Academy Press. Washington D.C, p:44.

15. Luna, L.G.(1988); Manual of Histology staining Methods of the Armed Forces Institute of Pathology. $3^{\text {rd }}$ ed. New York, Mac Graw-Hill Book Company, pp:38-76 and 222-223.

16. Parede, L., Young. P.L. (1990); The pathogenesis of velogenic Newcastle disease virus infection of chickens of different ages and different levels of immunity. Avian Dis. 34: 803-808.

17. ELISA - SYNBIOTICS corporation (1997-2003).

WWW.

Symbiotic.com

18. Dashab, G., Sadeghi G. and Mehri, M. ( 2007); Performance and humeral immune response to Newcastle disease in two strains of broiler chickens. J. Anim. Vet. Adv.,6(3): 451- 453.

19. Al-Shahery, M.N., Al-Zubeady A.Z. and Al-Barood, S. Y. ( 2008); Evaluation of cell-mediated immune response in chickens vaccinated with Newcastle disease virus. Iraqi. J. Vet. Sci., 22(1): 2124.

20. Bouzoubaa, K., Kissi, B. Kasmy, M. Waddahou S. and Tangarfi, M. (2005); Vaccination against Newcastle disease and Gumboro disease in backyard poultry: Apilot program in Morocco. In Abstract Book of the $14^{\text {th }}$ world Veterinary Poultry Congress, August 22-26, Istanbul, Turkey. Abs. No. 13$\mathrm{p}: 314$.

21. Jennifer, L.G., Edmund D.B. and Ketterson, D. (2003); Immune function across generations: Integrating mechanism and evolutionary process in maternal antibodies transmission. Proc.R.Soc. Lond. B, 270:23092319.

22. Reynolds, D.L. and Maraqa, A.D. ( 2000); Protection immunity against Newcastle disease. The role of cell mediated immunity, Avian Dis., 44: 145-159.

23. Sarker, N., Tsudzuki, M. Nishibori, M. Yasue $\mathrm{H}$. and Yammoto, Y. (2000); Cell mediated and humeral immunity and phagocytic ability in chicken lines divergently selected for serum immunoglobulin $\mathrm{M}$ and 
G levels. Poult. Sci., 79:17051709.

24. Vui T.Q., Lohr J.E., Kyule M.N., Zessinanl K.H. and Baumann P.O. ( 2002); Antibody levels against Newcastle disease virus, infectious bursal disease virus and avian influenza virus in rural chickens in Vietnam. Int. J. Poult. Sci. 1: 127132.

25. Ibrahim A.1, Ideris A. \& Babjee A.M. (1992); An overview of the use food based Newcastle disease vaccine in Malysia. In Newcastlein village chickens, Australian Centre for International Agricultural Reaserch (ACIAR), Canbera, pp: 75-78.

26. Islam M.R, Haque Q.M, Gissuddin M, Alam J. \& Rahman M.M. (2003); Assessment of maternally derived antibody of commercial flock against Newcastle disease . Proccedings of $3^{\text {th }}$ Intrnational Poultry Show and Seminar, Bangladesh-China Friendship Conference Centre, Dhaka, Bangladesh, pp: 89-93.

27. Ibrahim A.L, Lai M.C \& Aini I. (1983); Spray vaccination with an improved F Newcastle disease vaccines. A comparison of efficacy with the B1 and La Sota vaccine. Br. Vet. J. 139: 213-219.

28. Almassyl K, Barhouma N, El-Sabbgh A, Ibrahim SN, Boktor N, Khashaba E \& Gawad SA, (1979); Comparative immunization experiment with lentogenic Newcastle disease vaccine strain. J. Egypt Vet. Med. Assoc. 35: 95104.

29. Bermdez AJ and Stewart Brown B.(2003); Disease prevention and diagnosis. In disease of poultry (Y.M> Saif, ed.), $11^{\text {th }}$. Ed. Iowa State University Press, Ames.: 1754.
30. Marangons and Busani L.(2006); The use of vaccination in poultry production Rev. Sc., Tech. off. Int. Epiz.: 26(1): 265-274.

31. Bankowski R.A \& Hill R.W. (1954); Factors influencing the efficiency of vaccination of chickens against Newcastle disease by the air born rout,. Proceeding of the $91^{\text {th }}$ Annual Meeting of American Association of Scattle, pp: 317-327

32. Winterfield R.W \& Seadle E.H. (1957); The immune response of chickens vaccinated at an early age with $B_{1}$ Newcastle disease virus administered through the drinking water under field condition. Poultry Sci. 36: 65-70.

33. Allan W.H, Lancaster J.H \& Tooth B. (1978a); Selection of vaccine seed strain. In Newcastle disease vaccines, Their Production and Use, Chapter 3, Food and Agricultural Organization of United Nation, Rome, pp: 10-18.

34. Allan W.H, Lancaster J.H \& Tooth B. (1978b); Vaccination Programes. In Newcastle disease vaccines, Their Production and Use, Chapter 11,. Food and Agricultural Organization of United Nation, Rome, pp: 93-102.

35. Toth T.E (2000); Nonspecific cellular defence of the avian respiratory system: a review. Dev. Comp. Immunol. 24: 121-139.

36. Mast J., Nanbru C., Van Den Berg T., and Meulemans G., (2005); Ultrastructural Changes of the Tracheal Epithelium after Vaccination of Day-Old Chickens with the La Sota Strain Of Newcastle Disease Virus. Vet. Pathol. 42:559-565.

37. SAS, (1988); Statistical analysis system, Users Guide: Statistics (Version 7) SAS-inst. Cary, NC., USA. 
38. Kotani T, Odagiri Y, Nakamura J, chickens infected with lentogenic Horiuchi T.(1987); Pathological changes of tracheal mucosa in تغير ات ما بعد ألتلقيح لبعض أللقاحات ألمستخدمة ضد مرض النيوكاسل في محافظة ألسليماتية Newcastle disease virus. Avian Dis. 31:491-497.

عماد أدوار عبد ألأحد

كلية الطب البيطري /جامعة السليمانية الخلاصة

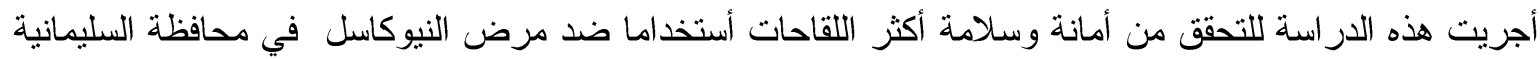

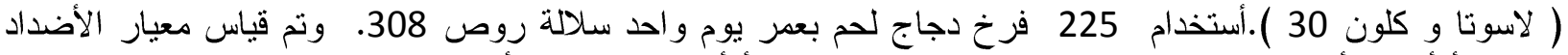

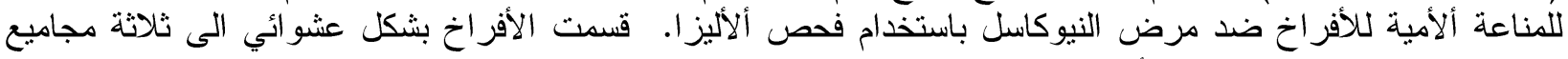

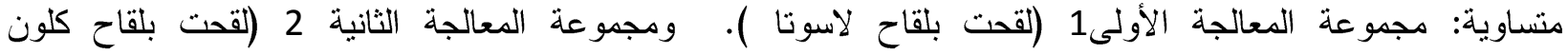

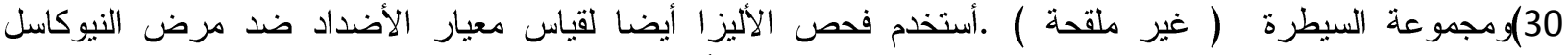

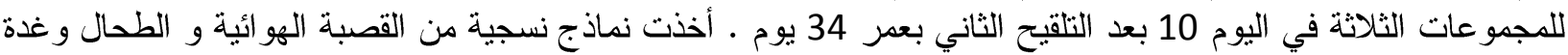

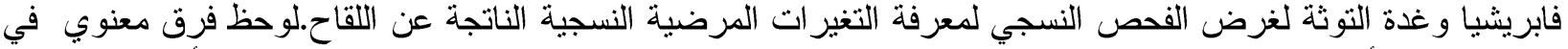

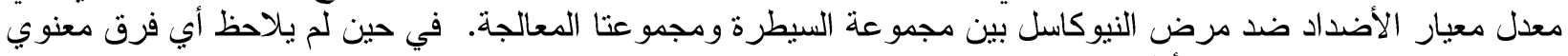

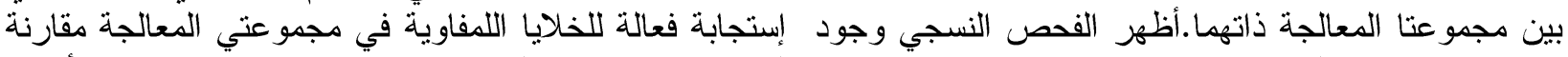

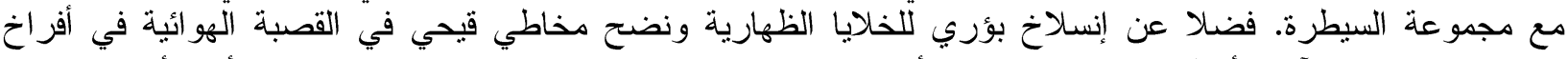
مجموعة المعالجة الآولى.أوظحت لنا هذه الدراسة أن لقاح كلون 30 له تقريبا كفاءة لقاح لاسوتا نفسها و أكثر أمانا منه. 